\title{
SOME PERSONAL REFLECTIONS ON THE ESTABLISHMENT OF THE PHILADELPHTA TAX REVIEW BOARD
}

\author{
Abraham L. Fremedman $\dagger$
}

The creation and development of the Philadelphia Tax Review Board reversed a long-established attitude of local governments in Pennsylvania toward their taxpayers. It heralded the end in Philadelphia of more than an archaic and broken-down system of collection of city taxes; it marked an end to the exercise of the sovereign taxing power in the primitive spirit of power unrestrained by right. For the first time the collection of taxes was established on a businesslike basis, and the government undertook to deal with its taxpayers not as suzerain and vassal but as creditor and debtor.

The Tax Review Board originated in the home rule charter of Philadelphia. As a member of the Charter Commission ${ }^{1}$ and its drafting committee, ${ }^{2}$ I was privileged to participate in the establishment and development of the Board as an instrument of government. Because the Charter Commission left the jurisdiction and final composition of the Tax Review Board to be determined by the council, it fell to me as city solicitor to draft the ordinance which made the Board a functioning agency. ${ }^{3}$ Some personal recollections on the evolution of the Board may therefore be of interest as an introduction to the detailed and detached study of its operations which has been made by Stanford Shmukler under the auspices of the Institute of Legal Research of the University of Pennsylvania Law School and financed by a grant from the Thomas Skelton Harrison Foundation.

From the start, there were grave obstacles to be overcome in dealing with the city's tax assessment and collection system. The Board of Revision of Taxes, in which was vested the power to assess real and personal property for purposes of taxation, considered itself beyond the Charter Commission's statutory authority as well as constitutionally immune from change, and its view was shared by many

†LL.B. 1926, Temple University; City Solicitor of Philadelphia, 1952-1956.

1 The Philadelphia Charter Commission was composed of Frederic D. Garman, chairman; Lewis M. Stevens, secretary; Joseph F. Burke; Robert J. Callaghan; Clarence K. Crossan; Tanner G. Duckrey; Abraham L. Freedman; Helen E. Heydrick; Ralph Kelly; Frederic R. Mann; Robert T. McCracken; Herbert R. Millen; Thomas B. K. Ringe; William A. Schnader; and Robert C. White.

2 The drafting committee consisted of William A. Schnader, chairman; Robert T. McCracken; and Abraham I. Freedman.

3 Later it was my responsibility to supervise the drafting of the final version of the ordinance, as it appeared in PhILAdELPHIA, PA., Code OF General Ordinances $\S 19-1701$ (1956). 
members of the Commission. ${ }^{4}$ It was my view, however, that the Board of Revision of Taxes was not protected by any constitutional provision and that, in any event, the home rule act could be amended so that the Charter Commission would admittedly have power to deal with it. In October 1950, a month after the Charter Commission issued its first printed draft, ${ }^{5}$ I circulated among the members of the Commission my formal comments on the draft. I suggested a provision that, "if and when" the home rule act authorized it, the Board of Revision of Taxes be abolished and all its functions other than those relating to appeals from assessments be transferred to an office of tax assessment ${ }^{6}$ headed by a chief tax assessor; the appellate functions would then be transferred to the Tax Review Board. ${ }^{7}$ These proposals were rejected, however, and the Charter Commission decided to deal only with the offices and functions of the city government. ${ }^{8}$

The Charter Commission was also divided on whether the preaudit functions of the city controller should be continued. Some thought that because the new director of finance was to perform preaudits, it would be undesirable to have the function duplicated by the city controller. Others believed a double check would prove useful and pointed out that the pre-audit power of the city controller was so inherently a part of his duties that its removal might run afoul of article XIV, section 1 , of the state constitution which made the controller a constitutional county officer, beyond the reach of legislation. This was the view that ultimately prevailed.

4 There was doubt whether the First Class City Home Rule Act, PA. Stax. AnN. tit. 53, $\$ 13101-57(1957)$, authorized county as well as city home rule. Nor was the effect of the city-county consolidation amendment to the constitution certain. (Art. XIV, \& 8, was then pending in the legislature) There were questions whether the Charter Commission would have authority under the amendment to deal with county offices and whether the amendment would be self-executing or require implementing legislation. Moreover, the home rule act expressly stated that the city had no power to intrude upon acts of the general assembly "providing for the assessment of real or personal property and persons for taxation purposes." PA. STAT. ANN. tit. 53, \&13133(a) (9) (1957).

5 This draft, officially designated Draft III, was the third considered by the Commission.

8 This would be a division in the office of the director of finance.

7 The Tax Review Board would also have assumed the functions of the Board of Revision of Taxes with respect to the Boards of View and the assessment of damages and benefits for property taken by eminent domain.

8 The charter did, however, provide that any additional executive and administrative powers conferred on the city by amendment of the constitution or by statute should be yested in the officers, departments, boards, and commissions created by the charter, according to such distribution as the city council might by ordinance determine. If it were not practicable to allocate new powers and duties in this way, then the charter authorized the council to create new offices, boards, and commissions. Philladelphia Home Rule Charter \$1-102(2). A later attempt, based on this provision, to abolish by ordinance the Board of Revision of Taxes and without additional legislative grant to establish in substance the plan which I had proposed, failed by the narrowest margin. Commonwealth ex rel. Truscott v. Philadelphia, $380 \mathrm{~Pa}$. 367,111 A.2d 136 (1955). 
In the preliminary drafts of the charter, the Tax Review Board (then called simply a "review board") was conceived as a departmental board and placed initially in the department of revenue collections, ${ }^{9}$ then in the department of finance, ${ }^{10}$ and finally in the department of collections. ${ }^{11}$ Although originally its purpose was to determine interdepartmental disputes, ${ }^{12}$ its function was later expanded to include the hearing of taxpayers' appeals from determinations of the amount of any tax due the city where the exercise of discretion was authorized by ordinance or statute. ${ }^{13}$ Ultimately, however, the Commission was unable to agree upon the jurisdiction of the Tax Review Board and left that task to the council. ${ }^{14}$ The membership of the Board was accordingly dealt with in preliminary fashion. ${ }^{15}$

The reform government headed by Mayor Joseph S. Clark, Jr., was sworn into office on January 7, 1952, the same day the home rule charter went into effect. ${ }^{16}$ But for two years, until September 1953, the Tax Review Board provisions of the charter were a dead letter. No jurisdiction for it had been prescribed, and the three ex-officio members were absorbed in the exacting work of implementing the new charter and establishing the new reform government. In January 1953 a draft of an ordinance dealing with the Tax Review Board was transmitted from the law department to Councilman Lewis M. Stevens, chairman of the finance committee of the council. The ordinance, which defined the jurisdiction of the Board, provided for an enlarged membership from which the previously designated city officials were omitted. ${ }^{17}$ Shortly thereafter, Mr. Stevens introduced the ordinance,

${ }^{9}$ Proposed Philadelphia Home Rule Charter, Draft I §501(j).

10 Proposed Philadelphia Home Rule Charter, Draft II §3-100(1).

11 Proposed Philadelphia Home Rule Charter, Draft III $\S 3-100(\mathrm{k})$; similarly Phinadelphia Hone Rule Charter §3-100(f).

12 Proposed Philadelphia Home Rule Charter, Draft I §§1102(f), (g).

13 Such determinations would be made by the department of collections with the approval of the auditing department, or where these two departments had disagreed, by the director of finance. Proposed Philadelphia Home Rule Charter, Draft III $\$ \$ 7-207$ to 7-209. Earlier provisions had dealt similarly with the subject. Proposed Philadelphia Home Rule Charter, Draft II \$§15-1211, -1212.

14 Phinadelphia Home Rule Cerarter $\S 6-207$ : "The Tax Review Board shall perform such duties as the Council shall from time to time impose upon it."

15 Phinadelphia Home Rule Charter \& 3-914: "[T] The Tax Review Board shall consist of the Director of Finance, the City Solicitor and the City Treasurer. If and when the Council shall so ordain, the Board shall consist of not more than five members . . . . One member shall be an accountant and one a lawyer."

16 The charter was adopted by the voters on April 17, 1951. On November 6, 1951, the city-county consolidation amendment to the constitution was approved.

17 On February 11, 1953, I delivered to the president of the council Formal Opinion No. 60, 1953 Ops. (PhILADELPHIA) CITY Solicitor 5, which ruled that the council had power to enlarge the Board to a membership of five and might exclude the named officials, but that the charter required all appointments to be made by the mayor. Philadelphia Home Rule Ceiarter § 3-207. 
but it was not until August 20, 1953, that the council adopted it; it was then signed by the mayor and became effective September 24, 1953..$^{18}$

In drafting the ordinance, I was resolved that the jurisdiction of the Tax Review Board be broadened far beyond what had been contemplated by the Charter Commission. Two aspects of the new city government's experience led to this conclusion: first, the hardships visited upon taxpayers because of the modernization of the city's tax collection system; and second, the mercantile tax license cases. In the process of modernization, old accounts were being dredged up, of which taxpayers had heard nothing for many years. The records by which many of these claims could be supported or contested had become unavailable. The primitive rule prevailed that in the absence of statute ${ }^{19}$ a taxpayer could neither recover back taxes he had erroneously paid ${ }^{20}$ nor avoid liability for interest and penalties if he withheld payment of the tax because of a dispute as to its validity or applicability. ${ }^{21}$ Payment was therefore required of all the old bills, together with accumulated interest and penalties which often far exceeded the amount of the tax. It was paradoxical that the government's effort to establish a nonpolitical and impersonal tax collection system, instead of receiving universal approbation, was in many instances imposing hardship and distress. ${ }^{22}$

18 Philadelphia, Pa, Tax Review Board Ordinance, Sept. 9, 1953, 1953 PrmADELPHIA ORDINANCES 478-84.

19 Statutory mechanisms directed toward providing relief for the taxpayer were not always effective. Early acts authorized and directed the payment of refunds under certain circumstances. Act of March 30, 1859, PA. STAT. ANN. tit. 53, §17055 (1957) ; Pa. Laws 1929, act 518, as amended, Pa. Laws 1935, acts 260, 395 (authorization only); Pa. Laws 1901, act 140. See Philadelphia, Pa., Ordinance of Dec. 22, 1922, 1922 PhILAdELPHIA ORdinances 687. But not until 1943 did any statute provide that a taxpayer could compel a refund. Pa. Laws 1943, act 162, \$\$1-2; see Girard Trust Co. v. Philadelphia, 359 Pa. 319, 325, 59 A.2d 124, 127 (1948). Philadelphia, Pa., Ordinance of July 18, 1944, 1944 Philadelpeia Ordinances 119, provided for refund of certain taxes and license fees and other moneys "erroneously or inadvertently paid," if timely application for refund were made. That ordinance created a board consisting of the receiver of taxes, the city controller, and the city treasurer, to pass on refunds. The 1943 act was narrowly construed: Pittsburgh Coal Co. v. Forward Twp. School Dist., $366 \mathrm{~Pa}$. 489, 78 A.2d 253 (1951), held that only tax bills paid under mistake of fact were "erroneously or inadvertently paid"; where payment was made under a protest that the tax was legally ineffectual, no refund could be compelled. Moreover, the act of 1943 was limited by its langtuage to taxes paid on real or personal property or license fees and, therefore, it did not give a taxpayer the right to compel refund of the mercantile license tax, see notes 23-25 infra and accompanying text, which was an excise or franchise tax. See Royal McBee Corp. Tax Case, $393 \mathrm{~Pa}$. 477,143 A.2d 393 (1958).

20 See Royal McBee Corp. Tax Case, supra note 19. (1954).

21 See Graybar Elec. Co. v. Pittsburgh School Dist., 378 Pa. 294, 106 A.2d 413

22 Efforts to alleviate the situation had been made. See Philadelphia, Pa., Ordinance of July 10, 1952, 1952 PhILAdelphia ORdinances 327-28 (authorizing certain water bill refunds); Philadelphia, Pa., Ordinance of Oct. 30, 1952, 1952 PhILAdelpendA ORDINANCES 488-89 (providing six-year limitation period for wage and net profits tax claims). 
As soon as the mercantile license tax ordinance ${ }^{23}$ was passed, a number of suits in equity were brought by taxpayers, and lower court decisions enjoined enforcement of the ordinance in all but a few unimportant areas. The supreme court finally held that, with some exceptions, the mercantile license tax was due from all of the plaintiffs. ${ }^{24}$ Meanwhile, interest and penalties had accrued on the tax. It seemed clear to me that under these circumstances the rigid rule with respect to interest and penalties should not apply to these taxpayers: they had been under the protection of injunctions granted by the courts of common pleas, maintained by the supreme court's denial of supersedeas. I ruled, therefore, that none of the parties litigant-nor those who had stood by awaiting the outcome-was liable for interest or penalties pending final determination of the controversy. ${ }^{25}$

Accordingly, the purposes sought to be achieved by the tax review board ordinance were: (1) to provide for refund of payments not due the city, including interest and penalties, whether such payments were for taxes or for other charges; and (2) to provide for the compromise of outstanding claims held by the city. The ordinance, therefore, conferred authority on the revenue commissioner, with the approval of the Tax Review Board, to grant refunds on the payment of any tax, water or sewer rent, license fee, or other charge, or interest or penalties thereon, upon his determination that the payment had been made under mistake of law or fact or under an invalid law. It authorized the commissioner to grant refunds without the approval of the Board in cases where overpayment resulted from duplication of payments, or mathematical error in computation of amount, or other mechanical mistake such as typographical error. ${ }^{28}$ Any denial by the commissioner of a refund was made appealable to the Board. ${ }^{27}$ The commissioner was also authorized, subject to the approval of the Board, to make compromises on both the principal and accrued interest or penalties of any

23 Philadelphia, Pa., Mercantile License Tax Ordinance, Dec. 9, 1952, 1952 РншіDELPHIA ORDINANCES 515-23.

24 National Biscuit Co. v. Philadelphia, $374 \mathrm{~Pa} .604,98$ A.2d 182 (1953). The Philadelphia Bar Association had urged the view that the mercantile license tax was inapplicable to lawyers on the ground that they were officers of the court, licensed by the court to practice before it. As applied to lawyers, it was contended, the tax constituted an infringement of the judicial power. I disagreed with this argument but consented to a test case because the view was sincerely held. The lawyers' case was successful in the lower court; meanwhile, some lawyers had paid the tax but most of them awaited the decision on appeal. The supreme court reversed the holding of the court of common pleas and declared that lawyers were subject to the tax. Sterling v. Philadelphia, $378 \mathrm{~Pa}$. 538, 106 A.2d 793 (1954).

25 Similar rulings were promulgated with respect to the lawyers' suit, during the pendency of which doctors, dentists, architects, and engineers had not paid the tax.

26 Philadelphia, Pa., Tax Review Board Ordinance §§5, 7, Sept. 9, 1953, 1953 Philadelphia Ordinances 480, 481-82.

27 Philadelphia, Pa., Tax Review Board Ordinance §7(e), Sept. 9, 1953, 1953 Peiladelphia ORdinances 482. 
tax or charge on his determination that such compromise was in the best financial interest of the city. ${ }^{28}$ Denial of compromise by the commissioner was made nonappealable. ${ }^{29}$

The policy manifested locally in the adoption of the tax review board ordinance in 1953 was reflected later on a broader scale. The Act of June 21, 1957, ${ }^{30}$ eliminated the former statutory requirement that before refund could be compelled payment must have been made "erroneously or inadvertently," which was construed to mean under mistake of fact. ${ }^{31}$ In sweeping terms, the 1957 act provides that when any taxpayer has paid into the treasury of any political subdivision, "voluntarily or under protest,"

any taxes of any sort, license fees, penalties, fines or any other moneys to which the political subdivision is not legally entitled; then, in such cases, the proper authorities of the political subdivision, upon the filing with them of a written and verified claim for the refund of the payment, are hereby directed to make, out of budget appropriations of public funds, refund of such taxes, license fees, penalties, fines or other moneys to which the political subdivision is not legally entitled. ${ }^{\mathbf{2}}$

Thus, at last, the taxpayer is rid of the need to make protest when he pays a tax, penalty, or fine to which the taxing authorities are "not legally entitled." In such circumstances the refund of such moneys is directed to be made to the taxpayer..$^{33}$

In the course of drafting the tax review board ordinance, one of the questions which arose was whether the ordinance should state that the Board was bound by the opinions of the city solicitor on all questions of law. The charter provides generally that all officers, departments, boards, and commissions of the city are bound by the rulings of the law department, ${ }^{34}$ and for many years all legal questions relating to city taxes had in fact been determined by members of the city solicitor's staff. Still, since we were embarking upon a venture as yet unknown to Philadelphia, it seemed to me the wiser course not to

28 Philadelphia, Pa., Tax Review Board Ordinance $\S 5$, 8, Sept. 9, 1953, 1953 Phiradelphia Ordinances 480, 482-83.

20 Philadelphia, Pa, Tax Review Board Ordinance §8(b), Sept. 9, 1953, 1953 Philladelphia Ordinances 482.

30 Pa. Stat. Ann. tit. 72, $\$ 5566$ b, c (Supp. 1960).

31 See note 19 supra.

32 Pa. Stat. Ann. tit. 72, §5566b (Supp. 1960). The claim must be filed within two years of payment and resort to the refund rights created by the statute may not be had where the taxpayer has available a specific remedy under any other statute, ordinance, or resolution. Compare PhILAdelphia, PA., Code of General ORdiNANCES \$19-1703(1) (1956) (six-year limitation period).

33 See Royal McBee Corp. Tax Case, 393 Pa. 477, 483, 143 A.2d 393, 396 (1958).

34 Phitadelphia Home Rule Charter $\$ \$ 4-400$ (a), 8-410. 
restrict the developments which might occur under the new ordinance but rather to observe their evolution. The ordinance, therefore, provided that the city solicitor or any deputy or assistant designated by him should act as the legal adviser of the Tax Review Board. ${ }^{35}$ This provision added nothing new to the law; it left open, of course, the basic issue whether the Board would be bound by rulings of the city solicitor on questions of law. It was my policy to avoid any collision between the Board and the law department on questions of law inherent in matters that came before the Board. Informally, therefore, for purposes of adjudicating tax questions of law, I permitted the views of the Board to prevail without objection-as if they were the expressions of the law department. And events as they unfolded made it increasingly ill-advised to attempt to separate questions of law from questions of fact. To have made the Board do this and submit questions of law to the law department for decision would have rendered the rest of its work impossible and, to any mind of real quality, uninteresting and undesirable. In retrospect it seems to me that it has proved desirable to have refrained from an immediate insistence upon the jurisdiction of the law department and to have permitted the procedure before the Board to take its evolutionary course. This is an area in which, with goodwill between the law department and the Tax Review Board, no harm, but good, has come from leaving the question open.

In the light of this historical background, the study which follows is of absorbing interest. No one who has observed the operations of the Board can doubt its value. It is, of course, a matter of high public policy that those assessed by the taxing authorities should have an appropriate tribunal to which they can present their complaints and from which they can secure a speedy decision. It is especially gratifying that an end has been made of the difficulties of determining whether a tax was paid by mistake of law or fact, or paid under protest, and that a policy has been established by which the city will return to its taxpayers moneys which do not belong to it.

35 Philadelphia, Pa, Tax Review Board Ordinance §4(c), Sept. 9, 1953, 1953 Phinadelphia Ordinances 480. 